\title{
The relationship of graft survival and herpes simplex virus latency in recipient corneal buttons
}

\author{
Orhan Aydemir' \\ Peykan Türkçüoğlu' \\ Yasemin Bulut ${ }^{2}$ \\ Ahmet Kalkan ${ }^{3}$
}

'Fırat University School of Medicine, Department of Ophthalmology, Elazığ, Turkey; ${ }^{2}$ Fırat University School of Medicine, Department of Microbiology, Elazığ, Turkey; ${ }^{3}$ Fırat University School of Medicine, Department of Infectious Diseases, Elazığ, Turkey

Correspondence: Peykan Türkçüoğlu Firat University School of Medicine, Department of Ophthalmology, Elazığ, Turkey

Tel +904242333555

Fax +904242388096

Email peykan74@yahoo.com
Purpose: To demonstrate relationship between herpes simplex virus (HSV) corneal latency and graft survival.

Methods: Prospective case control study. 28 recipient corneal buttons and donor cornea-scleral remnants were examined for HSV DNA with polymerase chain reaction (PCR). None of the recipient had a history of HSV infection. Serum samples of graft recipients were analyzed for the presence of anti-HSV IgG and IgM with enzyme-linked immunosorbent assay technique. All corneas were free of stromal scarring or epithelial defect before sampling and had an endothelial cell density of $>2000$ cells $/ \mathrm{mm}^{2}$.

Results: In twenty three patients (82\%) anti-HSV IgG was detected in serum. In none of the recipients anti-HSV IgM was positive. HSV DNA was positive in six out of twenty eight $(21 \%)$ of the recipient corneal buttons and none of the donor cornea-scleral remnants. In eighteenmonths follow-up period three out of six (50\%) HSV DNA positive and one out of twenty-two (4.5\%) HSV DNA negative patients experienced late endothelial failure that was statistically significantly different $(\mathrm{p}=0.022)$.

Conclusion: Even without a history of HSV keratitis, presence of latent HSV virus in recipient cornea is an important risk factor for subsequent graft survival.

Keywords: herpes simplex virus, polymerase chain reaction, corneal latency, corneal graft survival

\section{Introduction}

Graft failure, defined as the irreversible loss of the central transparency of the transplanted cornea, is a frustrating experience for the patient and the surgeon. Irreversible rejection, glaucoma, infection, primary failure, late endothelial failure are some of the causes of graft failure. Late endothelial failure is defined as a gradual graft decompensation without any history of a rejection episode and an apparent cause which is unresponsive to corticosteroids.

Herpes simplex virus (HSV) is a DNA virus that induces keratitis, uveitis, or retinitis in immunocompetent subjects. After invading cornea, virus established latency in trigeminal ganglion (Shimeld et al 1995) and can be reactivated by stimuli such as sunlight, emotional stress, fever, and corticosteroids usage (Beyer et al 1989).

Herpetic infection also involves corneal endothelial cells. Most common cause of graft failure in metaherpetic recipients is the HSV reactivation (Sterk et al 1995). HSV infection caused severe endothelial cell loss in corneal organ culture (Cleator et al 1994) and has been implicated in some cases of primary graft failure (Cleator et al 1994; Cockerham et al 1997; De Kesel et al 2001). These evidences show that HSV might be the cause of some failures of corneal grafting.

The aim of our study was to establish whether the presence of HSV, as demonstrated by polymerase chain reaction (PCR) in donor or recipient corneas in whom 
no previous history of herpes simplex keratitis (HSK), could correlate with graft outcome over a 18 -months period.

\section{Material and method}

The study adhered to the Declaration of Helsinki and Good Clinical Practice guidelines. The subjects were enrolled after Institutional Review Board approval. Written informed consent was taken from 28 recipients (12 males and 16 females; mean age $54 \pm 16.2$ years; age range $24-73$ years), who underwent corneal transplantation between 2001 and 2004 because of pseudophakic bullous keratopathy ( 9 patients), keratoconus (7 patients), corneal dystrophy (4 patients), corneal opacity due to trauma (4 patients), alkali burns (2 patients), and trachoma (2 patients) (Table 1$)$. Written informed consent was taken from the families of cornea donors (14 males and 14 females; mean age $31.9 \pm 8.6$; age range $19-48$ years). None of the participants had a history of HSV infection. All corneas were free of stromal scarring or epithelial defect before sampling and had an endothelial cell density of $>2000$ cells $/ \mathrm{mm}^{2}$. Donor corneal remnants and recipient corneal buttons were preserved in a clot tube at $-80{ }^{\circ} \mathrm{C}$ for polymerase chain reaction (PCR) analysis.

\section{HSV serology}

An enzyme-linked immunosorbent assay (ELISA) technique was used to detect anti-HSV IgG and IgM in serum samples of graft recipients.

\section{Tissue preparation and DNA extraction}

The specimens were crushed in phosphate buffered saline, and then centrifuged at $13.000 \mathrm{rpm}$ for 15 minute at $20{ }^{\circ} \mathrm{C}$. The pellets were left to stand in a digestion buffer containing $10 \mathrm{mM}$ Tris-HCl, pH7.4, $100 \mathrm{mM}$ $\mathrm{NaCl}$, and $25 \mathrm{mM}$ EDTA, $0.5 \%$ sodium dodecyl sulfate (SDS), $200 \mathrm{mg} / \mathrm{ml}$ of proteinase $\mathrm{K}$ for overnight at $37^{\circ} \mathrm{C}$ (Shimizu and Burns 1995). After proteinase $\mathrm{K}$ inactivation, $0.5 \mathrm{ml}$ of saturated phenol $\mathrm{pH} 8$ was added. Tubes were centrifuged at $1500 \mathrm{~g}$ for $15 \mathrm{~min}$, and supernatant was transferred to another tube. Then, phenol-chloroformisoamyl alcohol (25:24:1 ratio) was added, and the microtubes were centrifuged at $1500 \mathrm{~g}$ for $15 \mathrm{~min}$. Supernatant was then transferred to another tube and chloroformisoamyl alcohol (24:1) was added and then centrifuged at $1500 \mathrm{~g}$ for $15 \mathrm{~min}$. DNA was precipitated using absolute ethanol and ammonium acetate $(7 \mathrm{M})$ at $-20{ }^{\circ} \mathrm{C}$ overnight. The solution was centrifuged at $16,000 \mathrm{~g}$ for $20 \mathrm{~min}$. After decanting the supernatant, the pellet was washed with
$70 \%$ ethanol and diluted with $20 \mu \mathrm{l}$ sterile distilled water for PCR.

\section{Amplification}

We used $50 \mu \mathrm{l}$ of reaction mixture containing $2 \mathrm{U}$ of Taq polymerase (Promega Corp., Madison, WI), $10 \times$ PCR buffer (Tris-HCL 100 mM, pH 8.0; KCl 500 mM), $200 \mu \mathrm{M}$ of deoxyribonucleotide triphosphate dATP, dTTP, dCTP, dGTP, for each and and $15 \mathrm{mM}$ of $\mathrm{MgCl}_{2}$. A total of $500 \mathrm{ng}$ of each DNA extract was then subjected to HSV PCR using specific primers KS30 (5'-TTC AAG GCC ACC ATG TAC TAC AAA GACGT-3') and KS31 (5'-GCC GTA AAA CGG GGA CAT GTA CAC AAA GT-3'). Positive cases resulted in amplification of a 431-bp fragment located on the HSV glycoprotein B gene. This target sequence is specific to HSV types 1 and 2 and is known not to code for any other human herpesviruses. The PCR cycling conditions were pretreatment at $94{ }^{\circ} \mathrm{C}$ for $3 \mathrm{~min}$, followed by 35-39 cycles of denaturation at $94^{\circ} \mathrm{C}$ for $1 \mathrm{~min}$, annealing for $50 \mathrm{~s}$, and extension at $72{ }^{\circ} \mathrm{C} 1 \mathrm{~min}$ followed by an additional $7 \mathrm{~min}$ at $72{ }^{\circ} \mathrm{C}$. Purified DNA from HSV-1 McKrae strain of HSV-1 was used as a positive control, and sterile distilled water, replacing DNA, was used as a negative control. Amplicons of the expected size (431 bp) were visualized by electrophoresis with $2.0 \%$ agarose gel stained with ethidium bromide under ultraviolet light (Figure 1). The positive results double-checked by PCR.

\section{Statistical analysis}

Statistical analyses were carried out by employing the Statistical Package for Social Sciences software 11.0 for Windows package software (SPSS, Inc., Chicago, IL). The Fischer's exact chi-square test was used and a $p$ value less than 0.05 were considered as statistically significant.

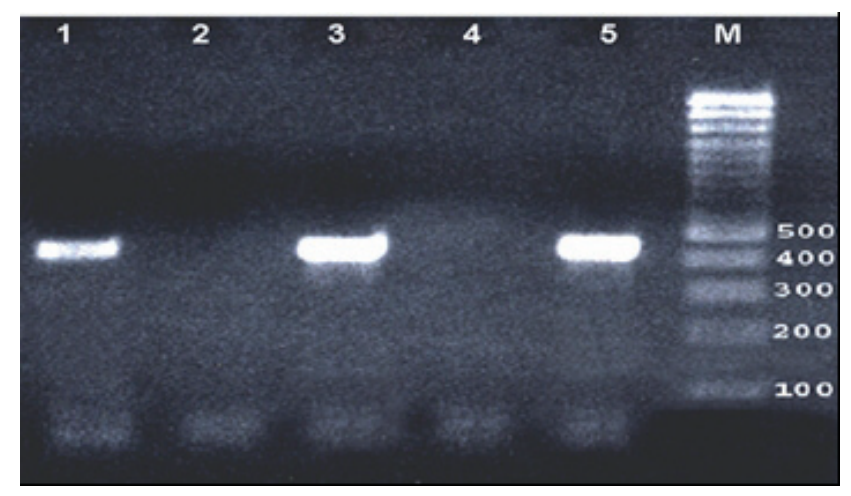

Figure I PCR with HSV KS30 primers (43I bp amplicon) were visualized by electrophoresis with $2.0 \%$ agarose gel stained with ethidium bromide under ultraviolet light. Lane I and 3 positive patient corneal specimens, lane 2 and 4 negative patient corneal specimens, lane 5 positive HSV McKrae strain control. 


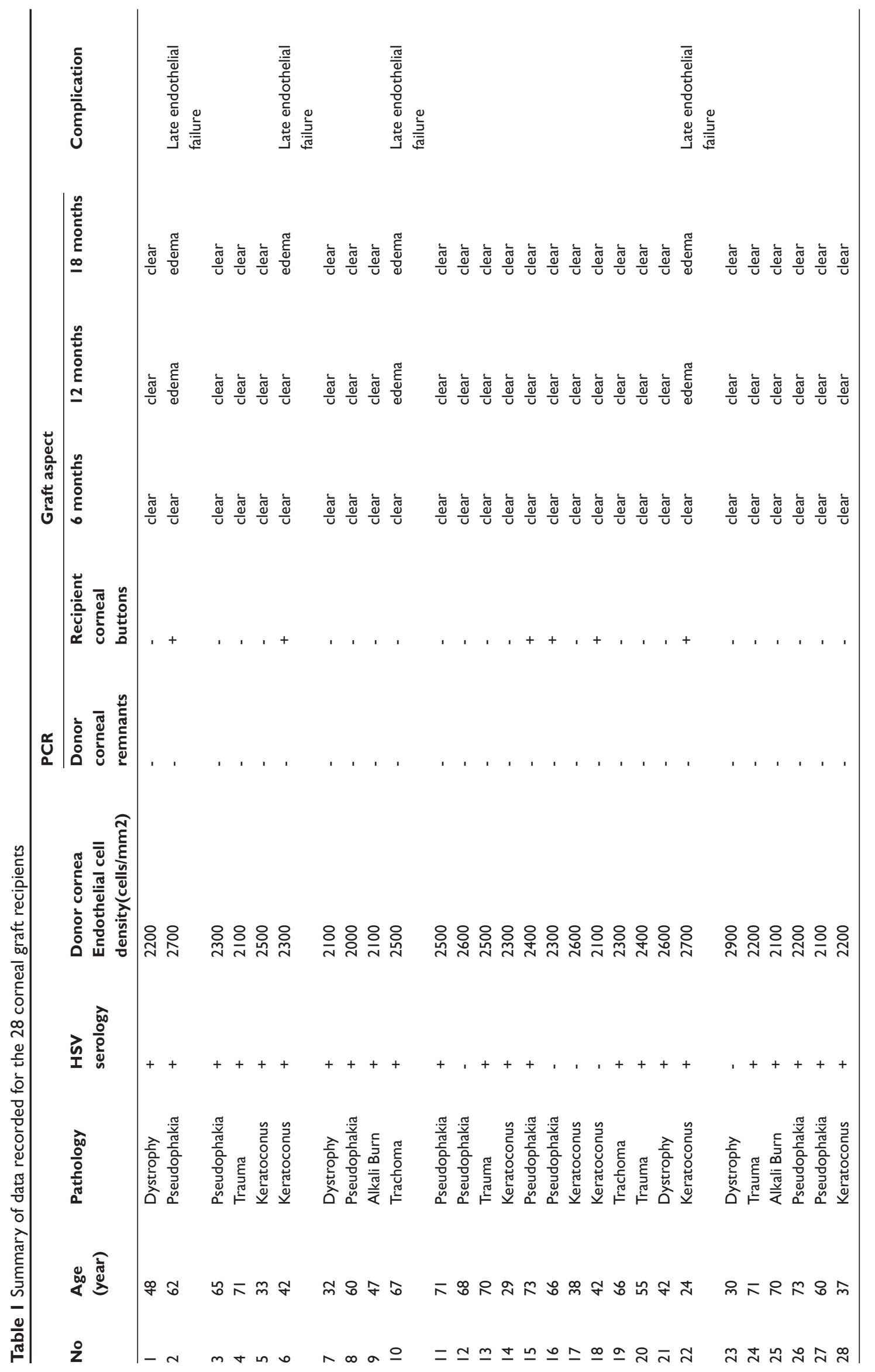




\section{Results}

Anti-HSV IgG was found in serum of twenty three patients (82\%). Anti-HSV IgM was not detected in any. A positive test result in the HSV PCR was obtained in six out of twenty eight $(21 \%)$ recipient corneal buttons and none of the donor cornea-scleral remnants. In the follow-up period four patients experienced late endothelial failure. In three of them HSV DNA were positive. Statistically significant difference was present between HSV DNA positive corneas and HSV DNA negative corneas in respect to late endothelial failure $(\mathrm{p}=0.022)$. Overall results are summarized in Table 1.

\section{Discussion}

Primary HSV infection usually occurs in childhood, and seroprevalence increase with age up to $85.3 \%$ in sexually active adults (Liesegang 2001; Dolar et al 2006). The HSV-1 DNA was detected in trigeminal ganglion in 74 of 121 patients (61\%) in a study (Motani et al 2006). Therefore, even without a history of HSV infection, all patients are probable carrier of latent HSV virus in trigeminal ganglia.

One of important cause of corneal opacification is HSV keratitis in developing countries. Activation and centrifugal migration of latent virus from trigeminal ganglion is the pathogenesis of herpes simplex keratitis (HSK). HSV virus can also undergo latency and reactivation in the cornea as an extraneuronal site after HSK disease (Pavan-Langston et al 1989; Rong et al 1991). In previous studies HSV detection rate by $\mathrm{PCR}$ ranged from $32 \%$ to $82 \%$ in donor cornea buttons of subjects with a past history of herpes keratitis (Cantin et al 1991; van Gelderen et al 2000; Kaye et al 2000).

In corneas of clinically unsuspected herpetic keratitis patients HSV DNA was also isolated by PCR (Cantin et al 1991; Kaye et al 2000). In different studies this rate was documented as 36\% (Cantin et al 1991), and 22\% (Kaye et al 2000). In our study we also demonstrated that six out of twenty eight $(21 \%)$ corneal transplant patient without clinically obvious herpetic keratitis were carrying latent HSV virus in their corneas.

Recurrence of a herpetic infection following corneal transplantation is the main reason for graft failure in penetrating keratoplasties for HSK (Sterk et al 1995). It was shown that HSV infection cause severe endothelial cell loss (Cleator et al 1994) and HSV infection was suspected as the cause of some cases of primary graft failure (Cockerham et al 1997; De Kesel et al 2001).

In patients with allograft failure without a history of HSK, an unexpected high number of HSV positive test results were found in recipient corneal buttons. Several stimuli related to corneal transplantation, such as surgical trauma, suture removal and immune reactions, the necessary application of local immunosuppression (Beyer et al 1989), may reactivate the virus. In these patients, no antiviral treatment was used since no obvious clinical signs of corneal HSV infection had been observed during the process of graft failure (Cook 1992). In our study, three out of six HSV DNA positive recipients $(50 \%)$ and one out of twenty-two DNA negative recipients $(4.5 \%)$ experienced late endothelial failure that is statistically significantly different.

Screening of donor cornea culture fluid for HSV DNA, using PCR assay is not recommended. Only 3.8\% of 80 corneas were positive for HSV and post transplant follow up of the three recipients revealed no evidence of HSV induced eye disease or primary graft failure (Morris et al 1996). In our study we could not demonstrate HSV DNA by PCR in any of the recipient remnants.

In conclusion presence of latent HSV virus in recipient cornea is an important risk factor for subsequent graft outcome. Therefore, even without a history of HSV keratitis, keratoplasty patient are at risk for graft failure due to HSV corneal latency.

\section{Acknowledgments}

We thank Dr. Ayhan Kubar for providing HSV McKrae strain used as positive control in the PCR analysis.

\section{References}

Beyer CF, Arens MQ, Hill JM, et al. 1989. Penetrating keratoplasty in rabbits induces latent HSV-1 reactivation when corticosteroids are used. Curr Eye Res, 8:1323-9.

Cantin EM, Chen J, McNeill J, et al. 1991. Detection of herpes simplex virus DNA sequences in corneal transplant recipients by polymerase chain reaction assays. Curr Eye Res, 10(Suppl):15-21.

Cleator GM, Klapper PE, Dennett C, et al. 1994. Corneal donor infection by herpes simplex virus: herpes simplex virus DNA in donor corneas. Cornea, 13:294-304.

Cockerham GC, Krafft AE, McLean IW. 1997. Herpes simplex virus in primary graft failure. Arch Ophthalmol, 115:586-9.

Cook SD. 1992. Herpes simplex virus in the eye. Br J Ophthalmol, 76:365-6.

De Kesel RJ, Koppen C, Ieven M, et al. 2001. Primary graft failure caused by herpes simplex virus type 1. Cornea, 20:187-90.

Dolar N, Serdaroglu S, Yilmaz G, et al. 2006. Seroprevalence of herpes simplex virus type 1 and type 2 in Turkey. J Eur Acad Dermatol Venereol, 20:1232-6.

Holbach LM, Asano N, Naumann GO. 1998. Infection of the corneal endothelium in herpes simplex keratitis. Am J Ophthalmol, 126:592-4.

Kaye SB, Baker K, Bonshek R, et al. 2000. Human herpesviruses in the cornea. Br J Ophthalmol, 84:563-71.

Liesegang TJ. 2001. Herpes simplex virus epidemiology and ocular importance. Cornea, 20:1-13.

Morris DJ, Cleator GM, Klapper PE, et al. 1996. Detection of herpes simplex virus DNA in donor cornea culture medium by polymerase chain reaction. Br J Ophthalmol, 80:654-7. 
Motani H, Sakurada K, Ikegaya H, et al. 2006. Detection of herpes simplex virus type 1 DNA in bilateral human trigeminal ganglia and optic nerves by polymerase chain reaction. J Med Virol, 78:1584-7.

Pavan-Langston D, Rong BL, Dunkel EC. 1989. Extraneuronal herpetic latency: Animal and human corneal studies. Acta Ophthalmol Suppl, 192:135-41.

Rong BL, Pavan-Langston D, Weng QP, et al. 1991. Detection of herpes simplex virus thymidine kinase and latency-associated transcript gene sequences in human herpetic corneas by polymerase chain reaction amplification. Invest Ophthalmol Vis Sci, 32:1808-15.

Shimeld C, Whiteland JL, Nicholls SM, et al. 1995. Immune cell infiltration and persistence in the mouse trigeminal ganglion after infection of the cornea with herpes simplex virus type 1. J Neuroimmunol, 61:7-16.
Shimizu H, Burns JC. 1995. Extraction of nucleic asids: Sample preparation from paraffin-embedded tissues. In: MA Innis, DH Gelfand, JJ Sninsky, (eds) PCR Strategies, London: Acad Pr. pp 32-38.

Sterk CC, Jager MJ, Swart-vd Berg M. 1995. Recurrent herpetic keratitis in penetrating keratoplasty. Doc Ophthalmol, 90:29-33.

van Gelderen BE, Van der Lelij A, Treffers WF, et al. 2000. Detection of herpes simplex virus type 1,2 and varicella zoster virus DNA in recipient corneal buttons. Br J Ophthalmol, 84:1238-43. 
